University of Nebraska - Lincoln

DigitalCommons@University of Nebraska - Lincoln

Faculty Papers and Publications in Animal

Science

Animal Science Department

February 1984

PREWEANING SURVIVAL IN SWINE: HERITABILITY OF DIRECT AND MATERNAL EFFECTS

William R. Lamberson

University of Nebraska-Lincoln

R. K. Johnson

University of Nebraska-Lincoln, rjohnson5@unl.edu

Follow this and additional works at: https://digitalcommons.unl.edu/animalscifacpub

Part of the Animal Sciences Commons

Lamberson, William R. and Johnson, R. K., "PREWEANING SURVIVAL IN SWINE: HERITABILITY OF DIRECT AND MATERNAL EFFECTS" (1984). Faculty Papers and Publications in Animal Science. 36.

https://digitalcommons.unl.edu/animalscifacpub/36

This Article is brought to you for free and open access by the Animal Science Department at DigitalCommons@University of Nebraska - Lincoln. It has been accepted for inclusion in Faculty Papers and Publications in Animal Science by an authorized administrator of DigitalCommons@University of Nebraska - Lincoln. 


\title{
PREWEANING SURVIVAL IN SWINE: HERITABILITY OF DIRECT AND MATERNAL EFFECTS'
}

\author{
William R. Lamberson ${ }^{2}$ and R. K. Johnson ${ }^{3}$ \\ University of Nebraska, \\ Lincoln 68583
}

\begin{abstract}
Summary
The heritabilities of direct and maternal effects on litter survival to weaning (LS) were estimated from records of 1,243 litters of pigs from the Nebraska Gene Pool population born from 1968 to 1981 . Heritabilities were estimated by: (1) weighted least-squares regressions of average survival for litters of sons on average survival for litters of their sire, (2) nested analysis of variance with LS fitted to a model including year-line and sire of litter, (3) weighted least-squares regression of average survival for the litter of daughters on the survival of the litter of their dam and (4) nested analysis of variance with LS fitted to a model including year-line and sire of dam of litter. Analyses were conducted with and without adjustment for litter size born. Estimates of the heritability of direct effects from methods 1 and 2 were negative. Adjustment to a common litter size born had no effect. If direct effects are considered to be negligible, as indicated by these analyses, then LS may be considered a trait of the dam. The heritability of maternal effects estimated from daughter-dam regression was $.01 \pm .02$. The estimate of heritability of maternal effects obtained from analysis 4 was $.07 \pm .03$. Again, there were no effects from adjustment to a common litter size born. These estimates were not significantly different and the pooled estimate was $.03 \pm .02$. These analyses indicate that some additive genetic variance might exist for maternal effects but none for direct effects on LS. Selection for increased survival is not expected to be successful.
\end{abstract}

\footnotetext{
${ }^{1}$ Published as Paper No. 7297 of Journal Series, Nebraska Agr. Exp. Sta.

${ }^{2}$ Present address: Anim. Sci. Dept., Univ. of Missouri, Columbia 65211.

${ }^{3}$ Depr. of Anim. Sci.

Received September 26, 1983.

Accepted January 25, 1984.
}

(Key Words: Swine, Survival, Heritability, Maternal Effect.)

\section{Introduction}

Increased use of computers by swine producers will facilitate utilization of complex selection criteria in the breeding program. Modeling studies have indicated the importance of high reproductive rate and viability of young for efficiency of production of swine (Tess et al., 1983). Currently, there is interest in estimating breeding values of sires for survival. However, few estimates of the necessary parameters are available. Genetic variation for survival is known to exist, as breed differences and heterosis have been reported (Smith and McLaren, 1967; Johnson and Omtvedt, 1973; Young et al., 1976; Johnson, 1981), but few attempts have been made to estimate the heritability of survival (Cummings et al., 1947; Bergheim, 1975; Strang and Smith, 1979).

The objectives of the present study were to estimate the heritabilities of direct and maternal effects for preweaning survival in swine.

\section{Materials and Methods}

Data were collected from 1968 to 1977 (period 1) and 1979 to 1981 (period 2) from the Nebraska Gene Pool population. Two lines made up the population during period 1 , a line selected for increased ovulation rate (OR) and a control line $(C)$. The population and its management during period 1 have been described by Zimmerman and Cunningham (1975). During 1978, the lines were repopulated by hysterectomy to the University of Nebraska Field Laboratory at Mead.

Two generations of relaxed selection accompanied relocation, after which the OR line was divided into three lines and selection began for decreased age at first estrus and increased 
litter size. Relaxed selection was continued in one line derived from the OR line, and the original $\mathrm{C}$ line was maintained.

Percentage survival of a litter (LS) was measured by dividing the number of genetic littermates alive at weaning (fostering was minimal) by the number of fully formed pigs, alive or dead, present at birth. No attempt was made to distinguish stillbirths from pigs dying shortly after birth. It is known from hysterectomies of sows near term that few fully formed pigs are dead in the uterus (N. R. Underdahl, personal communication). Most fully formed pigs that are stillborn then must die during parturition.

Only gilt litters were considered in the present study. Litters were weaned at $42 \mathrm{~d}$ in period $1 ; 28 \mathrm{~d}$ in period 2 . Inbreeding effects were not considered because the increase in inbreeding has been less than $1 \%$ /generation. Matings to minimize inbreeding were practiced, and there was little within line-generation variation in inbreeding coefficients.

Estimates of the heritability of LS were obtained from a pooled data set of records of 754 litters born during period 1 and 489 litters born during period 2. Methods used to estimate heritability were: 1) a weighted least-squares regression of average survival to weaning of litters of sons on average survival of the litters of their sire (OS), 2) a nested analysis of LS with year-line and sire of litter in the model (NSL), 3) a weighted least-squares regression of average survival of litter of daughters on the survival of the litter of their dam (OD), and 4) a nested analysis of variance of LS with year-line and sire of dam of litter in the model (NSD). The Statistical Analysis System nested procedure was utilized for paternal half-sib analyses and the general linear models procedure was utilized for regression analyses (SAS, 1979). Each estimate was obtained with and without adjustment for litter size born. Standard errors of these estimates were obtained by the method suggested by Becker (1964).

The correlation among full-sibs (tFS) for individual survival was obtained from variance components from a nested analysis of variance including year-line, sire and dam of litter in the model. Only data from period 2 were included in this analysis because no individual survival observations, only litter survival percentages, were available from period 1 . The value of this intraclass correlation was .16. This value represents likeness among littermates caused by additive direct, additive maternal, nongenetic maternal and nonmaternal common environmental effects.

\section{Results and Discussion}

The coefficient from the regression of progeny test of son on progeny test of sire was -.08 . Expectations of heritability from this regression are more complicated than for the usual regression of phenotype of offspring on phenotype of parent. The path coefficient diagram (figure 1) illustrates the sire-son case in which the mean survival of litters of a son

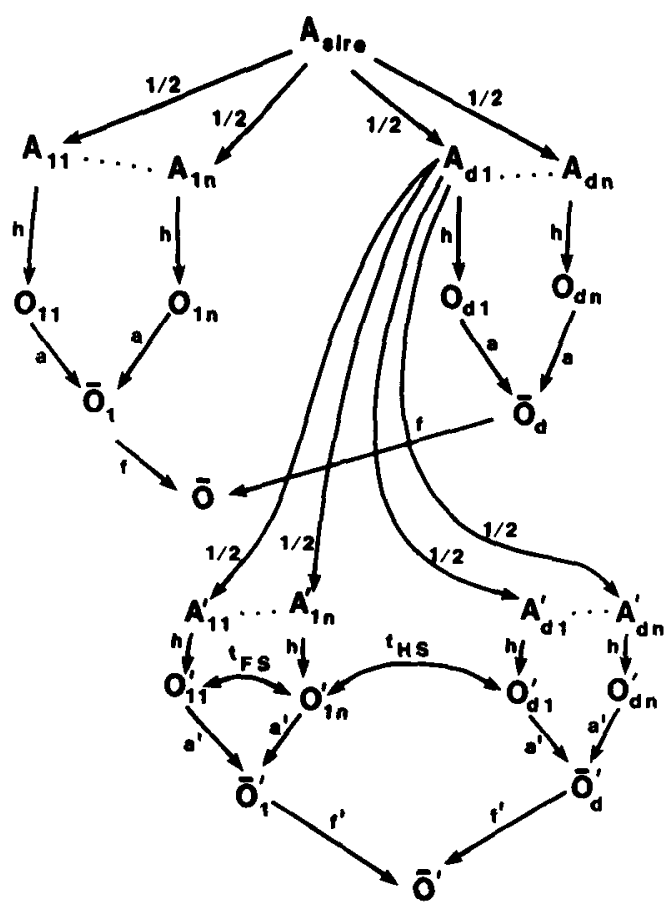

Figure 1. Diagram showing the relationship between the means of progeny of a son and his sire. Key for path diagram: ASIRE = breeding value of the sire of offspring $O_{i j}, A_{i j}=$ breeding value of $p i g j$ in litter $i$, $A_{\mathrm{dl}}=$ represents the breeding value of a son of the sire with breeding value ASIRE that was selected and subsequently mated to $\mathrm{d}$ females, $O_{\mathrm{jj}}=$ phenotypic value of $p i g j$ in litter $i, \bar{O}_{j}=$ percentage survival of litter $\mathrm{j}$ (litter mean), $\overline{\mathbf{O}}=$ mean survival of litters of a sire, $a=$ path coefficient representing the contribution of the survival of an individual pig to the litter percentage survival, $f=$ path coefficient representing the contribution of the percentage survival of a litter to the mean survival percentage of all litters of a sire, tFS = intraclass correlation among full-sibs (littermates) for survival, $\mathbf{t}_{H S}=$ intraclass correlation among half-sibs for survival, $=$ indicate breeding values, phenotypic values, litter means and sire family means for progeny of the son with breeding value $A_{\mathrm{dl}}$. 
$\left(A_{d 1}\right)$, represented by $\bar{O}^{\prime}$, is regressed on the mean survival of litters of his sire (ASIRE), represented by $\bar{O}$. The means for each breeding male were calculated as the mean of the percentage survival of the litters of his $d$ mates. Each litter consisted of $\mathbf{n}$ pigs/litter. The values of $n$ and $d$ used in calculations were the harmonic means of litter size born and number of mates/male, respectively. The expectation of the regression of progeny test of son on progeny test of sire, in terms of the path diagram (figure 1 ) is:

$$
\begin{gathered}
{ }^{b} \overline{\mathrm{O}}^{\prime}, \overrightarrow{\mathrm{O}}=1 / 2 \mathrm{~h}^{2} \mathrm{a}^{2} \mathrm{f}^{2} \mathrm{nd}\left[1+\frac{\mathrm{n}-1}{2}+\frac{\mathrm{n}(\mathrm{d}-1)}{4}\right] \\
=\mathrm{h}^{2}\left[\frac{1 / 4+\mathrm{n} / 8+\mathrm{nd} / 8}{1+(\mathrm{n}-1) \mathrm{r}_{\mathrm{FS}}+\mathrm{n}(\mathrm{d}-1) \mathrm{t}_{\mathrm{HS}}}\right] .
\end{gathered}
$$

Solution of this equation, assuming $t_{H S}=h^{2} / 4$, did not yield a simple expression in terms of heritability, but rather yielded the following:

$$
h^{2}=\frac{x b}{y+z b},
$$

where $b=$ offspring parent regression coefficient, $\mathrm{x}=1+(\mathrm{n}-1) \mathrm{t} F \mathrm{FS}, \mathrm{y}=1 / 4+\mathrm{n} / 8+\mathrm{nd} / 8$ and $\mathrm{z}=$ $-\frac{\mathrm{n}(\mathrm{d}-1)}{4}$. For this analysis, $\mathrm{n}=8.9, \mathrm{~d}=2.3$ and $t_{F S}=.16$. These correspond to $x=2.26, y$ $=3.92$ and $z=-2.89$. If more than one son/sire produced offspring, the mean of all sons' progeny was regressed on the sire's progeny mean weighted by the number of sons of the sire that reproduced (Kempthorne and Tandon, 1953). The heritability from OS was $-.04 \pm .02$ (table 1).

A second estimate of heritability of direct effects was obtained from NSL. The expectations of the intraclass correlation obtained from this analysis, -.02 , are complicated because the trait is expressed as a litter mean. This expectation is:

$$
{ }^{\mathrm{t}} \overline{\mathrm{O}}_{\mathrm{i}}, \overline{\mathrm{O}}_{\mathrm{j}}=\mathrm{h}^{2}\left[\frac{\mathrm{n} / 4}{1+(\mathrm{n}-1) \mathrm{t} F S}\right] .
$$

With $\mathrm{n}$ and $\mathrm{t}_{\mathrm{FS}}$ as above,

$$
h^{2}=1.02{ }^{t} \overline{\mathrm{O}}_{\mathrm{i}}, \overline{\mathrm{O}}_{\mathrm{j}} .
$$

The heritability from NSL was $-.02 \pm .04$ (table 1).

Both estimates of heritability of direct effects from sire analyses were negative. The heritability estimates from these analyses are free of bias, except for the effects of additive epistasis (Dickerson, 1969). We conclude from these estimates that additive variance for direct effects on LS is absent. There was no effect of adjustment to a common litter size born.

The coefficient from the regression of survival rate of daughters' litter on survival of dam's litter was .02. This estimate includes additive variance, additive maternal effects and the covariance of additive direct and maternal effects. If direct effects are considered to be zero, as indicated by the sire estimates, the regression coefficient from OD can be attributed to additive maternal effects. The expectation of this regression is:

$$
b=\frac{n h_{m}^{2}}{2\left[1+(n-1) t_{F S}\right]} .
$$

With $\mathrm{n}$ and $\mathrm{t}_{\mathrm{FS}}$ as above,

$$
\mathrm{h}^{2}=.51 \mathrm{~b} \text {. }
$$

The heritability of maternal effects from OD was $.01 \pm .02$ (table 1). Again, there was no effect of adjustment to a common litter size born.

TABLE 1. ESTIMATES OF THE HERITABILITY OF DIRECT AND MATERNAL EFFECTS FOR SWINE PREWEANING LITTER SURVIVAL

\begin{tabular}{llll}
\hline Analysis & $\mathrm{df}^{\mathrm{a}}$ & $\mathrm{h}^{2}$ direct & $\mathrm{h}^{2}$ maternal \\
\hline OS & 347 & $-.04 \pm .02$ & $.01 \pm .02$ \\
NSL & 520 & $-.02 \pm .04$ & $.01 \pm .03$ \\
OD & 610 & & $.07 \pm 07$ \\
NSD & 345 & & \\
\hline
\end{tabular}

\footnotetext{
${ }^{a}$ Error degrees of freedom for regression analyses and sire degrees of freedom for paternal half-sib analyses.
} 
The intraclass correlation from the NSD analysis gives another estimate of the heritability of maternal effects. The intraclass correlation was .065 . Again, since this trait is represented by a litter mean, the expectation of the intraclass correlation is not $1 / 4 \mathrm{~h}^{2}$ but rather:

$$
{ }^{\mathrm{t}} \overline{\mathrm{O}}_{\mathrm{i}}, \overline{\mathrm{O}}_{\mathrm{j}}=\mathrm{h}_{\mathrm{m}}^{2}\left[\frac{\mathrm{n} / 4}{1+(\mathrm{n}-1) \mathrm{t} F S}\right] \text {. }
$$

With $\mathrm{n}$ and $\mathrm{t}_{\mathrm{FS}}$ as above,

$$
\overline{h_{m}^{2}}=1.02 t_{\mathrm{O}_{i}}, \overline{\mathrm{O}}_{\mathrm{j}} .
$$

The heritability of maternal effects from NSL was $.07 \pm .03$ (table 1). Adjustment to a common litter size did not affect the magnitude of this heritability estimate.

The estimates of heritability of maternal effects from OD and NSL do not differ significantly and when pooled equal $.03 \pm .02$. This estimate is very close to those reported by Strang and Smith (1979). The low estimates of heritability of survival from the present study as well as those reported by Bergheim (1975) and Strang and Smith (1979) offer no encouragement to select for increased survival to weaning.

\section{Literature Cited}

Becker, W. A. 1964. Manual of Procedures in Quantitative Genetics. Washington State Univ., Pullman.
Bergheim, P. I. 1975. A study of the heritabilities and correlations among measures of performance and productivity in gilts. M.S. Thesis. Oklahoma State Univ., Stillwater.

Cummings, J. N., L. M. Winters and H. A. Stewart. 1947. The heritability of some factors affecting productivity of brood sows. J. Anim. Sci. 6:297.

Dickerson, G. E. 1969. Techniques for research in quantitative animal genetics. In: J. K. Loosli, R. Bogart and C. E. Terrill (Ed.) Techniques and Procedures in Animal Science Research. pp 36-79. Amer. Soc. Anim. Sci., Champaign, IL.

Johnson, R. K. 1981. Crossbreeding in swine: Experimental results. J. Anim. Sci. 52:906.

Johnson, R. K. and I. T. Omtvedt. 1973. Evaluation of purebreds and two-breed crosses in swine: Reproductive performance. J. Anim. Sci. 37: 1279.

Kempthorne, O. and O. B. Tandon. 1953. The estimation of heritability by regression of offspring on parent. Biometrics 9:90.

SAS. 1979. SAS User's Guide. Statistical Analysis System Institute, Inc., Cary, NC.

Smith, H. G. and J. B. McLaren. 1967. Performance of breeds and breed crosses in swine. Tennessee Agr. Exp. Sta. Bull. 434.

Strang, G. S. and C. Smith. 1979. A note on the heritability of litter traits in pigs. Anim. Prod. 28:403.

Tess, M. W., G. L. Bennett and G. E. Dickerson. 1983. Simulation of genetic changes in life cycle efficiency of pork production. II. Effects of components on efficiency. J. Anim. Sci. 56:354.

Young, L. D., R. K. Johnson and I. T. Omtvedt. 1976. Reproductive performance of swine bred to produce purebred and two-breed cross litters. J. Anim. Sci. 42:1133.

Zimmerman, D. R. and P. J. Cunningham. 1975. Selection for ovulation rate in swine: Procedures and ovulation response. J. Anim. Sci. 40:61. 